\title{
THE MAPPING AND ANALYSIS OF DIPHTHERIA CASES IN SURABAYA (2017-2018)
}

\author{
Adelita Setiawan $^{1}$, Lucia Yovita Hendrati ${ }^{2}$, Yudied Agung Mirasa ${ }^{3}$ \\ ${ }^{1,2}$ Faculty of Public Health, Universitas Airlangga, 60115 Surabaya, East Java, Indonesia \\ ${ }^{3}$ Center for Environmental Health Engineering and Disease Control Surabaya, Indonesia \\ Corresponding Author: Lucia Yovita Hendrati \\ E-mail: lucia-yh@fkm.unair.ac.id
}

\begin{abstract}
Diphtheria is an acute disease that attacks the airways and causes deaths. The risk factors for diphtheria are low Diphtheria-Pertussis-Tetanus (DPT) immunization coverage and an unhealthy home environment. One effort to control diphtheria is by providing information in the form of the patient's location that makes it easier to determine the target group of people intervened. The city of Surabaya experienced an increase of 50 diphtheria cases from 2017 to 2018. This study aimed to map and analyze diphtheria cases based on DPT immunization and healthy homes from 2017 to 2018 in the city of Surabaya. This study was classified descriptive analytic and used an ecological design. This study used the Pearson's correlation coefficient statistical test to analyze secondary data from the Surabaya City's Health Profile of 2017 to 2018. This study employed the Health Mapper 4.3.0.0 application and SPSS software version 23. The study variables were diphtheria cases, DPT immunization coverage, and the percentage of healthy homes in 2017 and 2018 in Surabaya. The results of the statistical test indicated that there was a moderate relationship between DPT basic immunization coupon with the number of diphtheria cases in 2018 ( $\mathrm{p}=0.007$; OR =0.471); while the percentage of healthy homes and the number of diphtheria cases in 2018 showed a strong correlation $(\mathrm{p}=0.002$; OR $=0.544$ ). The city experienced an increase in the number of diphtheria cases from 2017 to 2018 , as well as the rise in DPT immunization coverage and the percentage of healthy homes, which tended to be stagnant. DPT immunization coverage and the percentage of healthy homes based on the 2018 data were related to the number of diphtheria cases in Surabaya. Counseling for the people in the city should be conducted to ensure that their children get DPT immunization and maintain environment cleanliness for a healthy home.
\end{abstract}

Keywords: Diphtheria-pertussis-tetanus Immunization Coverage, Diphtheria, Surabaya, Mapping, Percentage of Healthy Homes

\begin{abstract}
ABSTRAK
Difteri merupakan penyakit akut yang menyerang saluran napas dan menyebabkan kematian. Faktor risiko difteri yaitu cakupan imunisasi DPT yang rendah dan keadaan rumah yang tidak sehat. Salah satu upaya pengendalian difteri yaitu pemberian informasi berupa lokasi dari penderita, untuk memudahkan menentukan sasaran kelompok masyarakat yang akan dilakukan intervensi. Kota Surabaya mengalami peningkatan sebanyak 50 kasus difteri pada tahun 2017 ke tahun 2018. Berdasarkan masalah tersebut makan dilakukan penelitian ini untuk memetakan dan menganalisis kasus difteri berdasarkan imunisasi DPT dan rumah sehat tahun 2017 ke tahun 2018 di Kota Surabaya. Penelitian ini menggunakan deskriptif analitik yaitu studi ekologi. Penelitian ini menggunakan uji statistik korelasi pearson. Penelitian ini memakai data sekunder berupa Profil Kesehatan Kota Surabaya tahun 2017 ke tahun 2018. Penelitian ini menggunakan aplikasi health mapper 4.3.0.0 dan SPSS versi 23. Variabel dalam penelitian yaitu kasus difteri, cakupan imunisasi DPT, dan persentase rumah sehat tahun 2017 dan tahun 2018 di Kota Surabaya. Hasil uji statistik menyatakan bahwa adanya hubungan antara cakupan imunisasi dasar DPT dengan kasus difteri tahun 2018 ( $p=0.007)$ dengan korelasi sedang $r=0.471$, sedangkan persentase rumah sehat berhubungan dengan kasus difteri tahun 2018 ( $p=0.002)$ dengan korelasi kuat $r=0.544$. Kota Surabaya mengalami peningkatan difteri pada tahun 2017 ke tahun 2018 diikuti dengan peningkatan cakupan imunisasi DPT dan persentase rumah sehat yang cenderung tetap. Cakupan imunisasi DPT dan persentase rumah sehat tahun 2018 berhubungan dengan kasus difteri di Kota Surabaya. Diperlukan upaya penyuluhan kepada masyarakat Kota Surabaya untuk memastikan anaknya mendapatkan imunisasi DPT dan selalu menjaga kebersihan rumah agar terciptanya rumah sehat.
\end{abstract}


Kata kunci: Cakupan Imunisasi Difteri-Pertusis-Tetanus, Difteri, Kota Surabaya, Pemetaan, Persentase Rumah Sehat

\section{INTRODUCTION}

Diphtheria is an acute disease caused by infection with Corynebacterium diphtheriae. This disease is characterized by the appearance of a thick membrane in the throat area. It causes difficulty in breathing, heart failure, paralysis, and death (Center for Disease Control and Prevention, 2018). Indonesia experienced a diphtheria outbreak in 2017 with 596 recorded cases. Most of the diphtheria outbreaks, amounting to 271 cases and 11 deaths, were in East Java province (Harapan et al., 2019).

Diphtheria occurs due to many factors, one of which is the absence of specific antibodies in the body. These antibodies are formed from the Diphtheria-Pertussis-Tetanus

(DPT) immunization process. DPT immunization has a vital role in keeping antibodies high (Mardiana, 2018), and thus it is necessary for everyone to get vaccinated, especially for DPT, to form antibodies and prevent diseases.

Housing conditions are also a risk factor affecting diphtheria cases in an area. Unhealthy housing conditions will support the growth of viruses and bacteria, one of which is Corynebacterium diphtheria. Preventing diphtheria could be done by improving the housing conditions to be healthier. A healthy house is one that meets health standards in terms of housing and sanitation facilities (Ministry of Health of the Republic of Indonesia, 2005; (Lubis and Warouw P, 2001).

Today's decision-making requires fast and accurate information based on local conditions (Wibowo, Indra, and Jumadi, 2015). Decision-making related to diphtheria eradication involves information regarding the location of the cases which will later be mapped according to the surrounding environment. From the mapping process, disease distribution patterns and risks can be identified. A Geographical Information System (GIS) is a system capable of processing data related to geographic locations or conditions (Setiawan et al., 2019). GIS, in health, could be used to measure disease risk by looking at the spread of a disease.

Efforts in eradicating infectious diseases, especially diphtheria, require data of the diseases on certain locations, which allows the mapping and analysis processes according to the surrounding environment (Saifudin, 2016). Mapping can be used to identify patterns of disease and spot disease risk. HealthMapper is a open source software recommended by the World Health Organization (WHO) operable at national to global scale. The data are presented using an area distribution map to show diphtheria cases with the DPT immunization status and the percentage of healthy homes.

According to the Regulation of the Indonesian Ministry of Health Number 12 of 2017 concerning the Implementation of Immunization, the immunization coverage target in the city/district is at $80 \%$. As a densely populated city, Surabaya had 29 diphtheria cases in 2017, which increased to 79 cases in 2018 (Surabaya City Health Office, 2018). This study aimed to map and analyze diphtheria cases in Surabaya based on risk factors for DPT immunization and the percentage of healthy homes from 2017 to 2018.

\section{METHODS}

This study used descriptive analytical method and was known as ecological research to describe the relationship between diphtheria cases and risk factors for DPT immunization coverage and the percentage of healthy homes. This study was conducted in 31 administrative sub-districts in Surabaya as the unit of analysis.

This study collected data from individuals with diphtheria, the percentages of healthy homes, and DPT immunization coverage for two years in 2017 and 2018 in Surabaya. The data were processed and analyzed by mapping the diphtheria cases combined with data on DPT immunization coverage and percentage of healthy homes from 31 sub-districts of the 
city. This study used research instruments in the form of data from the health profile of Surabaya. These include data on DPT immunization coverage, data on healthy homes, and data on the number of diphtheria cases in 2017 and 2018. Data analysis used Health Mapper 4.3.0.0 with the product version 4.03 and SPS version $23(\alpha=0.05)$.

Data on diphtheria cases, immunization coverage, and percentage of healthy homes in 2017 and 2018 were tested for normality before the statistical tests were carried out. The normality test used was the Kolmogorov-Smirnov Z. Further to this, this study used the Pearson's correlation coefficient statistical test to strengthen decision-making on the correlation of existing variables. This study had two hypotheses:

1. There was a relationship between DPT immunization coverage and diphtheria cases in 2017 and 2018.

2. There was a relationship between the percentage of healthy homes and diphtheria cases in 2017 and 2018.

The Pearson's correlation coefficient strength intervals observed from the r-value was (Sugiyono, 2007) as follows:

1. $0.00-0.199=$ Very low

2. $0.20-0.399=$ Low

3. $0.40-0.599=$ Medium

4. $0.60-0.699=$ Strong

5. $0.80-1.00=$ Very strong

DPT immunization coverage variable according to the Regulation of the Indonesian Ministry of Health Number 12 of 2017 concerning the Implementation of Immunization was classified into two: (1) low if immunization coverage is $<80 \%$ (red indicator), and (2) high if immunization coverage is $\geq 80 \%$ (green indicator).

The percentage of healthy homes in this study was classified into four categories: (1) poor: <69\% (red indicator), (2) medium: 69-83\% (orange indicator), (3) good: $83-99 \%$ (yellow indicator), and (4) best: $\geq 100 \%$ (green indicator) (Lubis and Warouw P, 2001).

The distribution of Diphtheria cases in 31 sub-districts of Surabaya was depicted using a dot symbol with one dot (.) meaning one diphtheria case. Meanwhile, DPT immunization coverage and the percentage of healthy homes were shown in color.

\section{RESULT}

The normality test results show that the three data categories in 2017 and 2018 were generally distributed because the significance value was $>0.05$. The requirements for the Pearson's correlation coefficient test had been met.

\section{Distribution of Diphtheria Cases with DPT Immunization Coverage}

Distribution of DPT Immunization Coverage with Diphtheria Cases in 2018

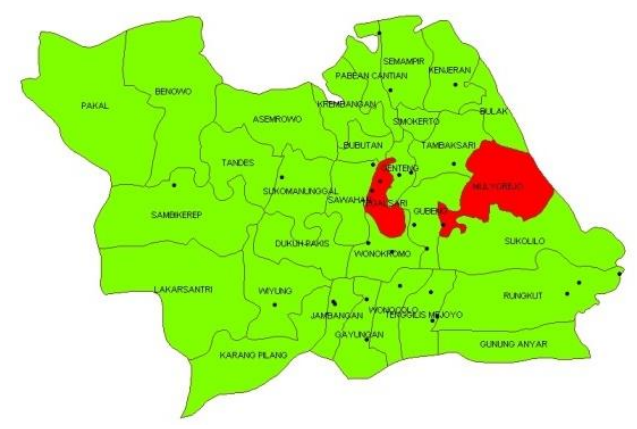

Distribution of DPT Immunization Coverage with Diphtheria Cases in 2018

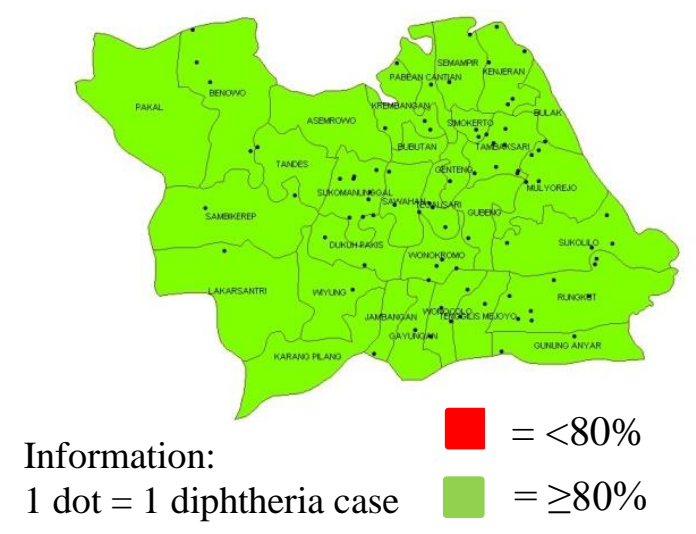

Source: Surabaya City Health Profile 2017-2018

Figure 1. Distribution of Diphtheria Cases with DPT Immunization Coverage in 2017 and 2018. 
Table 1. Results of Normality Test Data on Diphtheria Cases, Healthy Homes, and DPT Immunization Using the Kolmogorov-Smirnov Z Test

\begin{tabular}{lcc}
\hline \multirow{2}{*}{ Category } & \multicolumn{2}{c}{ Result } \\
\cline { 2 - 3 } & $\mathbf{2 0 1 7}$ & $\mathbf{2 0 1 8}$ \\
\hline Diphtheria Case & \multicolumn{1}{c}{31} \\
\hline $\mathrm{N}$ & 31 & 31 \\
Asymp. Sig (2-tailed) & 0.072 & 0.153 \\
\hline Healthy Home & \multicolumn{1}{c}{31} \\
\hline $\mathrm{N}$ & 31 & 31 \\
Asymp. Sig (2-tailed) & 0.648 & 0.621 \\
\hline DPT immunization & \multicolumn{2}{c}{} \\
\hline $\mathrm{N}$ & 31 & 31 \\
Asymp. Sig (2-tailed) & 0.369 & 0.127 \\
\hline
\end{tabular}

Source: Surabaya City Health Profile 2017-2018

DPT immunization coverage in 2017 was at $93.71 \%$, with 29 cases of diphtheria. The Mulyorejo and Tegalsari districts had immunization coverage of $<80 \%$ (red indicator), while other districts had immunization coverage of $\geq 80 \%$ (green indicator). Diphtheria mainly occurred in Rungkut and Tenggilis Mejoyo districts amounting to 3 cases, while 13 other subdistricts did not have any ( 0 cases $)$. DPT immunization coverage in 2018 increased by $3.47 \%$ with diphtheria also increasing by 50 cases from 2017.

Sukomanunggal district had experienced an increase in diphtheria by 7 cases from 2017 to 2018. In general, DPT immunization coverage was increasing, but there were still districts with decreased immunization coverage, namely Tambaksari district where immunization coverage reduced by $4.9 \%$ from 2017 to 2018. A decline in immunization coverage was accompanied by the highest increase in diphtheria, as many as 8 cases, in Surabaya.

Sub-districts that had immunization coverage below the target $(<80 \%)$ in 2017 with more than 1 diphtheria case $(6.45 \%)$ were Mulyorejo (73.31\%) and Tegalsari (73. $71 \%$ ) with 2 cases of diphtheria. Districts with high immunization coverage (> 80\%) with 0 cases of diphtheria totaled to 12 (38.71\%), which were: Tandes (95.91\%); Asemrowo (95.76\%); Benowo (99.58\%); Pakal
(100.98\%); Lakarsantri (91.66\%); Bubutan (92.89\%); Krembangan (93.22\%); Bulak (107.80\%); Gunung Anyar (93.27\%); Sukolilo (99.80\%); Karang Pilang (93.97\%); and Dukuh Pakis (98.06\%). In 2018, all sub-districts had immunization coverage above the set target $(\geq$ $80 \%)$. Mulyorejo (84.16\%), the sub-district with the lowest immunization coverage, had 4 cases of diphtheria. Districts with immunization coverage more than $80 \%$ with 0 cases of diphtheria amounted to 3 districts (9.68\%), which were: Asemrowo (106.23\%); Pakal (101.94\%); Karang Pilang (108.92\%).

\section{Distribution of Diphtheria Cases by Percentage of Healthy Homes}

Distribution of Percentage of Healthy Homes with Diphtheria Cases in 2017

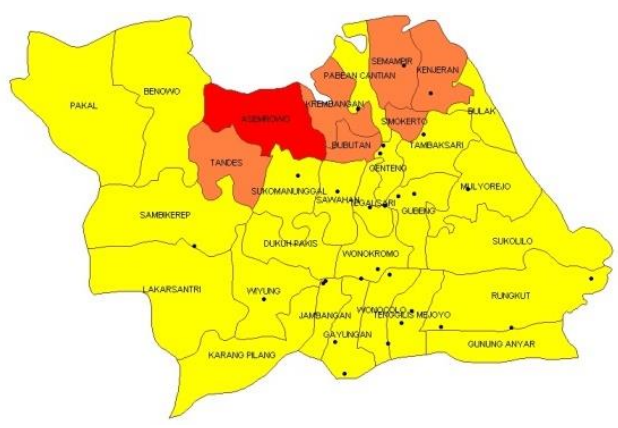

Distribution of Percentage of Healthy Homes with Diphtheria Cases in 2018

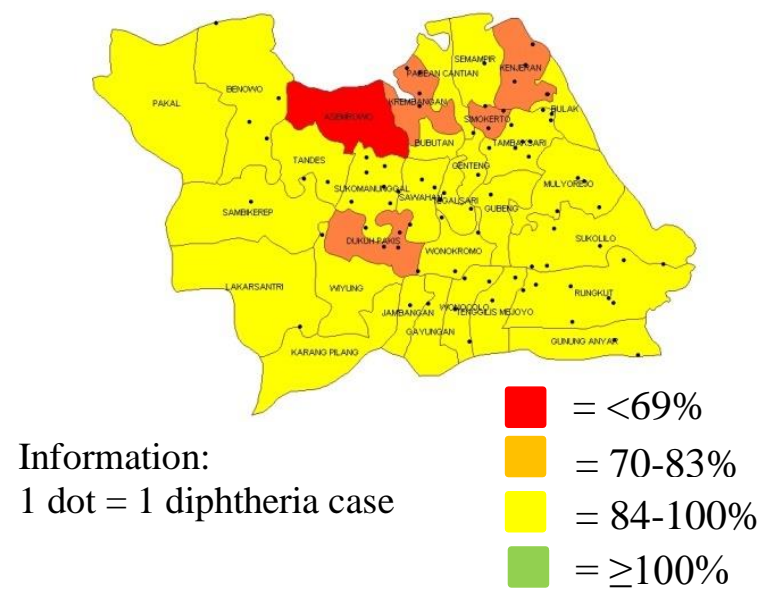

Source: Surabaya City Health Profile 2017-2018

Figure 2. Distribution of Diphtheria Cases by Percentage of Healthy Homes in 2017 and 2018. 
Figure 2 shows the percentages of healthy homes in 2017 were relatively the same as in 2018 , which was $87 \%$ even though there was an increase of 50 cases from 2017 to 2018. Asemrowo was the sub-district with the lowest percentage of healthy homes, with $63.40 \%$ in 2017 and no diphtheria case (red indicator). Apart from Asemrowo, Krembangan and Kenjeran districts had the percentage of healthy houses respectively at $76 \%$ (0 cases of diphtheria) and $76.10 \%$ (one diphtheria case) (orange indicator).

Asemrowo in 2018, again, had a percentage of healthy houses less than $69 \%$, in total of $63.61 \%$ (red indicator), while Krembangan and Kenjeran in 2018 had a percentage of healthy homes between $70-83 \%$ (orange indicator), with a successive percentage of $76.86 \%$ and $77.28 \%$, respectively. However, the percentage of healthy houses in these three sub-districts had increased. Asemrowo increased to $63.61 \%$, without case. Krembangan had increased to $76.8 \%$ with 4 cases, and Kenjeran to $77.27 \%$ with 5 cases.

Figure 2 also shows a decrease in the percentage of healthy homes in Dukuh Pakis district. In 2017, it had a percentage of $92.20 \%$ with 0 cases of diphtheria. Subsequently, in 2018, the percentage of healthy homes in Dukuh Pakis had decreased to $78.72 \%$ with 3 cases.

The sub-districts that experienced an increase in the percentage of healthy homes in 2017 to 2018 . Ten sub-districts (32.25\%) with permanent diphtheria cases or decreased cases included Semrowo $(63.39 \%$ to $63.61 \%$ with 0 constant diphtheria cases), Pakal (95.29\% to $95.66 \%$ with 0 cases), Bubutan (80.66\% to $83.06 \%$ with 0 cases), Bulak (82, $03 \%$ to $82.37 \%$ with 0 cases). The others were Tenggilis Mejoyo (84.73\% to $84.85 \%$ with diphtheria cases decreasing from 3 to 2), Karang Pilang (98.22\% to $98.33 \%$ with 0 cases ), Gayungan ( $94.82 \%$ to $95.82 \%$ with diphtheria cases decreasing from 2 to 1$)$, Jambangan $(89.29 \%$ to $94.78 \%$ with diphtheria cases reducing from 2 to 1 ), Wiyung (88.15\% to $95.82 \%$ with 1 case of permanent diphtheria), and Pabean Cantik (83.62\% to $84.93 \%$ with 1 remaining diphtheria case).

There were 3 districts $(9.68 \%)$ with decreased percentage of healthy homes and increased number of diphtheria cases from 2017 to 2018 . They were Rungkut (97.70\% to $93.92 \%$ with diphtheria cases increasing from 3 to 8 ), Mulyorejo ( $90.92 \%$ to $89.23 \%$ with diphtheria cases increasing from 2 to 4), and Dukuh Pakis (92.20\% to $78.72 \%$ with diphtheria cases increasing from 0 to 3 ).

\section{Relationship between DPT Basic Immunization Coverage and Diphtheria Cases in 2017 and 2018 in Surabaya}

Table 2. Pearson's Correlation Coefficient Test between DPT Immunization Coverage and Diphtheria Cases

\begin{tabular}{cccc}
\hline Year & $\begin{array}{c}\text { P- } \\
\text { values }\end{array}$ & r-values & Information \\
\hline 2017 & 0.686 & 0.076 & $\begin{array}{c}\text { Insignificant- } \\
\text { Very weak } \\
\text { Significant- } \\
\text { Moderate }\end{array}$ \\
\hline
\end{tabular}

Source: Surabaya City Health Profile 2017-2018

The Pearson's correlation coefficient test results stated that the coverage of DPT immunization with diphtheria cases in 2018 was significantly related $(\mathrm{p}=0.007)$ and had a correlation of 0.471 (moderate). However, in 2017, there was no significant relationship between DPT immunization coverage and diphtheria cases, proven with a p-value of 0.686 .

\section{The Relationship between the Percentage of Healthy Homes and Diphtheria Cases in 2017 and 2018 in Surabaya}

Table 3. Pearson's Correlation Coefficient Test between Healthy Homes and Diphtheria Cases

\begin{tabular}{cccc}
\hline Year & $\begin{array}{c}\text { P- } \\
\text { values }\end{array}$ & r-values & Information \\
\hline 2017 & 0.497 & 0.127 & $\begin{array}{c}\text { Insignificant- } \\
\text { Weak } \\
\text { Significant- } \\
\text { Strong }\end{array}$ \\
\hline
\end{tabular}

Source: Surabaya City Health Profile 2017-2018

The Pearson's correlation coefficient test showed that the percentage of healthy homes had a significant relationship with diphtheria cases in 2018 with a p-value of 0.002 and a correlation of 0.544 (strong). However, in 2017, there was no significant relationship 
between the percentage of healthy homes and diphtheria cases with a p-value of $0.497(p$ > $0.05)$.

\section{DISCUSSION}

\section{Diphtheria Cases based on DPT Basic Immunization Coverage}

The mapping of diphtheria cases based on DPT immunization coverage in 2017 and 2018 showed that Dukuh Pakis district had a decrease in DPT immunization coverage and an increase in the number of diphtheria cases. In other word, higher trends of diphtheria cases there was triggered by decreasing DPT immunization coverage. However, in Mulyorejo, immunization coverage and diphtheria cases had both increased in 2017 to 2018. The increase in diphtheria cases in Surabaya was mostly within the 20-44 age group (66 people) and those under 5 years old (10 people) (Surabaya City Health Office, 2018).

The DPT vaccine was formulated from diphtheria toxoids made from toxins produced by the Cornybacterium diphtheriae and from the weakening process of pertussis. The diphtheria vaccine could not be formulated with a single antigen form. The vaccine is combined with pertussis and tetanus toxoids (DPT) inactivation or only with the tetanus toxoid (DT and TD) (Food and Drug Administration 2015b). DPT primary immunization is made to be administered in children aged two months until 7 years of age. This vaccine is also given as a booster for children previously immunized with 3 or 4 doses (Food and Drug Administration, 2015b). A body that has been vaccinated will form immunity to protect itself from the Cornybacterium diphtheriae bacteria. The immunity built up in the body will decrease with increasing age, and thus the infant immunity disappears in adolescence. Eventually, a person can easily contract diphtheria even though their district's immunization coverage is high (Fitriansyah, 2018). Side effects of the vaccines are reactions at the injection site (pain, redness, swelling, fever, vomiting, and diarrhea) (Food and Drug Administration, 2015a).

There was a moderate correlation between DPT immunization coverage and diphtheria cases in 2018. This result is similar with Nailul Izza's research which found diphtheria was moderately associated with DPT/DT immunization coverage $(r=0.348)$. Low DPT/DT immunization coverage in a region will make diphtheria cases increase (Izza and Soenarnatalina, 2015). The results of other studies indicated that, in 2017, DPT immunization coverage was not related to the number of diphtheria cases. This occurred because several sub-districts with no diphtheria cases had high immunization coverage (immunization coverage of $\geq 80 \%$ ).

The high coverage of DPT immunization $(\geq 80 \%)$ in several sub-districts of Surabaya was also accompanied by an increase in diphtheria cases which initially did not exist. High immunization coverage did not ensure the freedom from disease in an area. This was due to immunization failures, one of which was merely intradermal injection of the DPT vaccine. Several procedural errors arose because of unsterilized syringes, errors in vaccine dissolution, transportation and storage that did not follow standard operating procedures, as well as ignore contraindications (World Health Organization, 2019).

\section{Distribution of Diphtheria Cases based on Percentage of Healthy Houses}

The mapping of diphtheria cases based on the percentage of healthy homes in Surabaya explained that in 2017 only one sub-district had a low percentage of healthy houses and high number of diphtheria cases. Thenceforth in 2018, three sub-districts had a decreased percentage of healthy homes but increasing diphtheria cases.

The results of this study showed that in 2017 the percentage of healthy homes was not related to the number of diphtheria cases. This was congruent with the fact that there was not many diphtheria cases in 2017. There were only 17 out of 31 districts with diphtheria, showing that the distribution was uneven. Table 3 presents the percentage of healthy homes and diphtheria cases in 2018. The results are in line with previous research which stated that environmental conditions and high diphtheria cases were related (Arifin and Prasasti, 2016). The environmental conditions influence the status of a healthy home. The criteria 
include non-waterproof house walls, building materials for safe ceilings (gypsum), non-dirt house floors, humidity at $40-60 \%$, natural lighting at least 60 lux, ventilation/house windows with an area of $\geq 20 \mathrm{~m}^{2}$, and density occupancy.

According to the Regulation of the Indonesian Ministry of Health Number 829/MENKES/SK/VII/1999 concerning Housing Health Requirements, the parameters of a healthy house include three groups, which are parts of the house, sanitation, and also resident behavior. Additionally, the health requirements for housing and residential environments are the location, air quality of the environment, and inside the house, noise, quality of soil, facilities, infrastructure, and existing disease vectors. Housing conditions can trigger the transmission of diphtheria from one individual to another through sneezes. The sputum droplets containing Corynebacterium diphtheriae bacteria can enter the body of others through the air.

Figure 2 shows that the percentage of healthy houses within the thirty-one subdistricts in Surabaya decreased probably because of the level of education. Puteri (2017) stated that the level of education was related to healthy home with an OR-value of 3.035. This meant that people who were at a low education level were three times more likely to have unhealthy house. Research conducted by Indah Dwi Kusumawati and Tjaturahono Budi Sanjoto stated that economic status was highly correlated with residential characteristics $(r=0.609)$. This was due to the population's various needs according to financial status. The higher the population's economic status, the more their needs (Kusumawati and Sanjoto, 2015).

\section{CONCLUSIONS AND SUGGESTIONS}

\section{Conclusions}

The mapping results in the thirty-one sub-districts of Surabaya show that even with an increase of 50 diphtheria cases in 2017 to 2018, the DPT immunization coverage and percentage of healthy homes tend to remain constant. The statistical tests showed that in 2018 DPT immunization coverage and the percentage of healthy houses were associated with diphtheria cases in Surabaya.

\section{Suggestions}

Dissemination of information or outreach to the community is crucial in ensuring that children get the DPT immunization. Furthermore, the cleanliness of the housing environment should always be carefully maintained to create a healthy home to prevent the transmission of diphtheria.

\section{REFERENCES}

Arifin, IF and Prasasti, CI, 2016. Factors Associated with Child Diphtheria Cases in Bangkalan Health Center 2016. Periodical Epidemiology, 5(1), pp.2636.

Food and Drug Administration, 2015a. With Tetanus and Pertussis (Trivalent). [online] National Drug Information Center, POM RI. Available at: $<$ http://pionas.pom.go.id/ >.

Food and Drug Administration, 2015b. Diphtheria Vaccine. [online] National Drug Information Center, POM RI. Available at: <http://pionas.pom.go.id/>.

Center for Disease Control and Prevention, 2018. Diphtheria. [online] US Department of Health \& Human Services. Available at: $<$ https://www.cdc.gov/>.

Ministry of Health RI, 2005. Indonesia Health Profile 2005. Jakarta.

Surabaya City Health Office, 2018. Surabaya City Health Profile 2018. [online] Surabaya.

Fitriansyah, A., 2018. Overview of Diphtheria Immunization History in Diphtheria Patients in Surabaya in 2017. Periodic Journal of Epidemiology, 6 (2), pp. 103-111.

Harapan, H., Anwar, S., Dimiati, H., Hayati, Z. and Mudatsir, M., 2019. Diphtheria Outbreak in Indonesia, 2017_ An Outbreak of The Ancient and Vaccine-Preventable Disease in The Third Millennium. Clinical Epidemiology and Global Health, 7 (2), 
pp.261-262.

Izza, N. and Soenarnatalina, 2015. Analysis of Spatial Data on Diphtheria in East Java Province in 2010 and 2011. Health System Research Bulletin, 18(2), pp.211-219.

Kusumawati, ID and Sanjoto, TB, 2015. The Relationship between Healthy Home Knowledge and Socio-Economic Status with the Quality of Residential Residents in Rowolaku Village, Kajen District, Pekalongan Regency. Geography, 3(3), pp. 45-54.

Lubis, A. and Warouw P, S., 2001. Description of Healthy Housing in Indonesia, SUSENAS 2001. Health Research Bulletin, 31 (4), pp.223-231.

Mardiana, DE, 2018. The Effect of Immunization and Population Density on the Prevalence of Diphtheria in East Java. Periodical Journal of Epidemiology, 6(2), pp. 122-129.

Regulation of the Minister of Health of Indonesia No 1077/Menkes/PER/2011 concerning Guidelines for Air Conditioning in Home Spaces.

Regulation of the Minister of Health of the Republic of Indonesia Number 12 of 2017 concerning the Implementation of Immunization.

Regulation of the Minister of Health of the Republic of Indonesia Number
829/MENKES/SK/VII/1999 concerning Housing Health Requirements.

Puteri, AD, 2017. Analysis of Factors Related to Healthy House Conditions in Bandur Picak Village, Koto Kampar Hulu District, 2017. Journal of Public Health, 1 (2), pp. 28-41.

Saifudin, N., 2016. Spatial Analysis and Modeling of Risk Factors for Diphtheria in Blitar Regency in 2015.

Setiawan, PB, Nur'aini, B., Hartono, H. and Tandelilin, RTC, 2019. Utilization of Geographical Information Systems for Mapping Periodontal Diseases Based on Environmental Factors in Pundong District, Bantul Regency. Indonesian Journal of Environmental Health, 18 (2), p.98.

Sugiyono, 2007. Statistics for Research. 12th ed. Bandung: CV ALFABETA.

Wibowo, KM, Indra, K. and Jumadi, J., 2015. The Geographical Information System (GIS) Determines the Location of Coal Mining in Bengkulu Province Based on Websites. Journal of Media Infotama, 11 (1), pp. 51-60.

World Health Organization, 2019. AEFI Reaction Due to Errors in Immunization Procedures. [online] World Health Organization. Available at: $<$ http://in.vaccine-safety-training.org/>. 